\title{
JWLS

\section{Thermal Analysis on Water-Simple Rankine Cycle and Combined Cycle for Waste Heat Recovery Flat Glass Factory}

Zefanya H. Wibowo, Budi U.K. Widodd and Djatmiko Ichsani

Department of Mechanical Engineering, Institut Teknologi Sepuluh Nopember, Surabaya 60111, Indonesia

Received: 1 January 2017, Revised:8 February 2017, Accepted: 15 March 2017

\begin{abstract}
One of the most important processes in glass production is the furnace section. The furnace's waste heat, which still has a temperature around $400-500^{\circ} \mathrm{C}$, is often released directly to the surrounding using stack. Waste Heat Recovery Generation (WHRPG) and Organic Rankine Cycle (ORC) is one of the many waste heat reusing schemes implemented to increase the efficiency of industrial processes by converting the waste heat into electricity. Two schemes of system will be studied in this research; there are Water-Simple Rankine Cycle (WSRC) and combined cycle (WSRC and ORC). In the WSRC, steam mass flow rate varied and found the highest performance to compare with combined cycle system. For combined cycle, the variations of system are steam mass flow rate, the evaporating temperature, flue gas temperature in stack and refrigerant as working fluid. For the result, the highest combined cycle perform is $5.89 \mathrm{MW}$ with steam mass flow rate $5 \mathrm{~kg} / \mathrm{s}$. Higher evaporating temperature $(160 \circ \mathrm{C})$ results in a higher combined cycle performance (5.96 MW), while, similarly, a lower flue gas temperature (120 $\circ \mathrm{C})$ also yields a higher combined cycle performance (6.3 MW). By varying the working fluids of R-11, R-113, and R-114.
\end{abstract}

Keywords: Combined Cycle, Flue Gas, ORC, Water Simple Rankine Cycle

\section{Introduction}

In a flat glass factory, a furnace is used in the production line to melt raw materials. A glass factory consumes a large amount of fuel to power its furnace, such as shown in the energy audit data in Table 1 . The process in furnace produces flue gas of high temperature. This gas is often released directly to the environment, wasting its potential. Table 1, for example, exhibits that flue gas wastes the heat potential of 17.76 MW. It should be noted that there are two production lines in the flat glass factory (A1 and A2) each of individual stack.

The potential of furnace waste heat poses as a challenge for engineers to develop systems converting waste heat into electricity. There are two schemes often used for regenerate waste heat: HRSG and ORC. HRSG is often applied in power plants where the temperature of flue gas is more than $400^{\circ} \mathrm{C}$. ORC, on the other hand, is used when the flue gas temperature is less than $200^{\circ} \mathrm{C}$. In the past years, studies regarding waste heat optimization have been proposed by Zhiwei Li [1] and Punjung Fatiri [2]. Zhiwei Li proposed thermal design of waste heat recovery power generation, which produced 5.2 MW power. The design is then confirmed by Punjung who applied it using Gate cycle software.

Despite these advances, new system designs are still needed for future development. This study develops system using Cycle Tempo to find match configuration of components and analyze power plant system using waste heat as heat source.

\section{Methods}

\subsection{Waste Heat Recovery Power Generation (WHRPG)}

Waste Heat Recovery Power Generator (WHRPG) is a modification of an ideal Rankine cycle. The system contains of superheater, evaporator, economizer, dearator, pump and turbine [1]. Instead of a boiler, the superheater, evaporator, and economizer are known as Heat Recovery Steam Generator (HRSG) system. WHRPG uses two working fluids: flue gas as the hot fluid and water as the cold one. Flue gas will flow from superheater to economizer until it reaches the stack where it will be released. Hightemperature flue gas is used to heat vapor in superheater become superheated steam.

In steam side, firstly steam from turbine is going to condense in a condenser with vacuum pressure. The benefit of vacuum pressure is to increase the efficiency of the system. Water from condenser is delivered to economizer by pump. Gradually, water from pump is heated in economizer, evaporator and superheater by flue gas. The similar system of WHRPG is shown by Figure 1 which shows the model of a Water-Simple Rankine Cycle (WSRC) system discussed in this study. It obvious that this system is similar to a WHRPG, in which flue gas from the furnace passes through HRSG system to heat and boil water.

\footnotetext{
*Email:buditem@me.its.ac.id

Phone:+6281553843834
} 
Table 1. Flue Gas Audit Data.

\begin{tabular}{lrrl}
\hline Plant & A1 & A2 & Unit \\
\hline Natural Gas Consumption & 3880 & 3985 & $\mathrm{Nm} 3 / \mathrm{h}$ \\
Flue gas mass flow rate & 79718 & 77225 & $\mathrm{~kg} / \mathrm{h}$ \\
Excess Air & 44 & 35 & $\%$ \\
Temperature of Flue gas (T) & 475 & 510 & $\mathrm{C}$ \\
Specific heat of flue gas (Cp) & 0.2609 & 0.262 & $\mathrm{kCal} / \mathrm{kg} \mathrm{C}$ \\
& 1.089095 & 1.08784 & $\mathrm{~kJ} / \mathrm{kg} \mathrm{C}$ \\
Heat Potential (Q) (T-120) & 8561.46 & 9100.91 & $\mathrm{~kW}$ \\
\hline \multicolumn{4}{c}{} \\
\hline $\mathrm{CO}_{2}$ & Flue Gas Contain \\
$\mathrm{H}_{2} \mathrm{O}$ & 10.8 & 11.45 & $\%$ \\
$\mathrm{~N}_{2}$ & 8.57 & 9.09 & $\%$ \\
$\mathrm{O}_{2}$ & 72.99 & 72.82 & $\%$ \\
Other & 6.81 & 5.82 & $\%$ \\
\hline
\end{tabular}

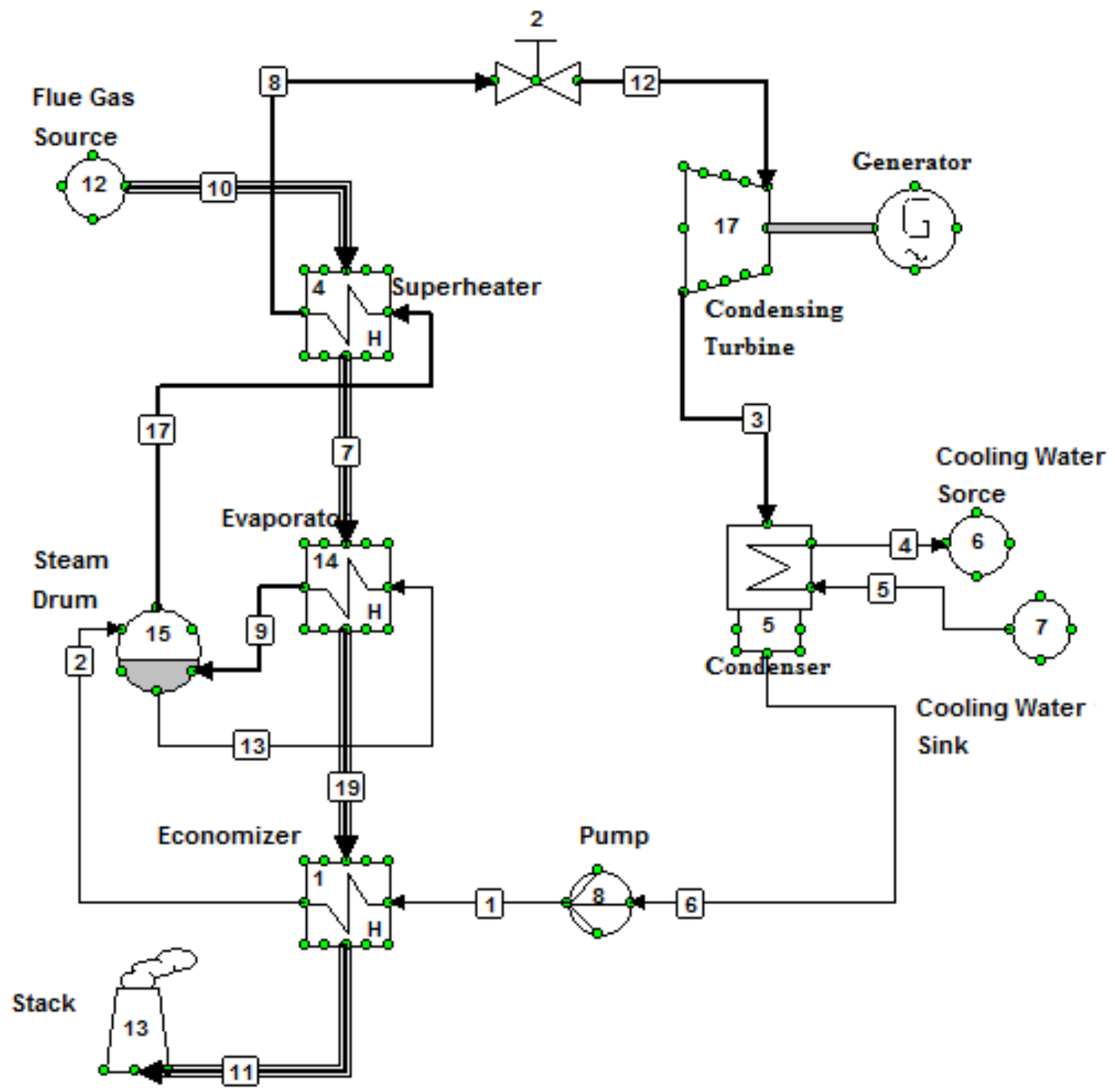

Figure 1. Cycle Tempo Modeling for Water-Simple Rankine Cycle. 


\subsection{Organic Rankine Cycle}

Organic Rankine Cycle (ORC) is a modified Rankine Cycle. The differences between ORC and conventional Rankine cycle are the working fluid and the heating component. Components of Rankine Cycle are boiler, turbine, condenser, and pump [3] but heating component in ORC is evaporator. The ORC's working fluid is organic, such as silicon oil, hydrocarbon, fluorocarbon, and refrigerant, which have a characteristic of having the superheated area less than $200^{\circ} \mathrm{C}$. Heating component in ORC is evaporator. The simplest form of ORC show in Figure 2 is composed of four components: evaporator, turbine, condenser, and pump. The processes in each component are as follows:

- Process 3-4 is isentropic expansion process in turbine. Superheated refrigerant from evaporator is rotated the turbine's blades.

- Process 4-1 is condensing process. Refrigerant vapor from turbine is going through an isobaric phase change inside the condenser to become liquid.

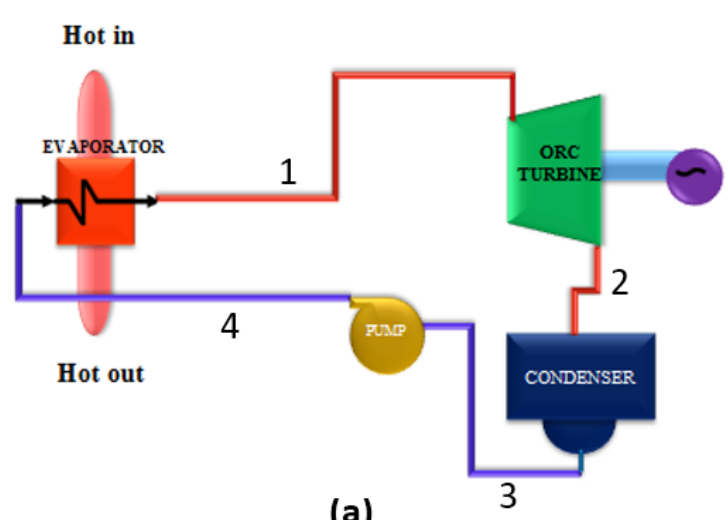

- Process 1-2 is isentropic compression process. Refrigerant from condenser is pumped from vacuum to operating pressure in evaporator

- Process 2-3 is heating process inside boiler. The refrigerant is heated to reach a certain hightemperature condition before re-circulated throughout the system.

Halocarbon refrigerant is selected to run this system. This type of refrigerant has one or more kind of halogen elements such as chlorine, bromine, and fluorine. Table 2 shows some type of refrigerant. There are some factors to consider in selecting refrigerant for ORC:

1. Refrigerant is not corrosive for the system.

2. Refrigerant is not flammable and has good temperature stability.

3. Refrigerant is not poisonous and easy to detect when leak occurs.

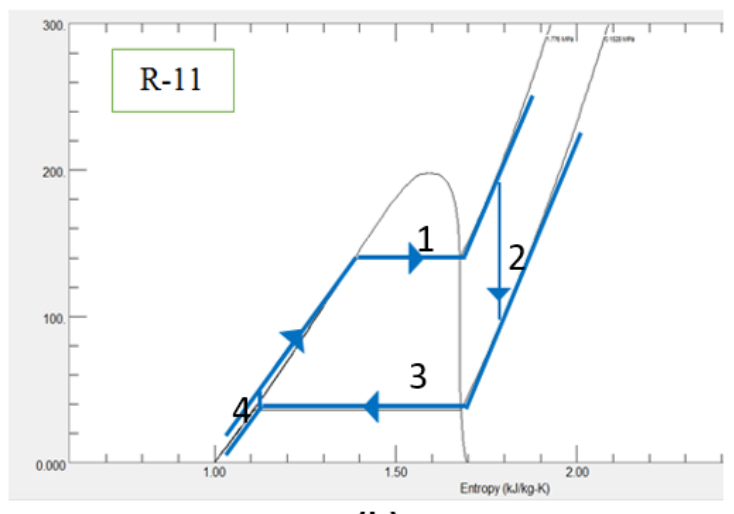

(b)

Figure 2. (a) Organic Rankine Cycle (b) T-s Diagram Organic Rankine Cycle.

Table 2. Type of Halocarbon Refrigerant

\begin{tabular}{lll}
\hline Refrigerant (R) & Name & Formula \\
\hline R11 & Trichloromonofluoromethane & $\mathrm{CCl}_{3} \mathrm{~F}$ \\
R12 & Dichlorodifluoromethane & $\mathrm{CCl}_{2} \mathrm{~F}_{2}$ \\
R22 & Monochlorodifluoromethane & $\mathrm{CHCLF}_{2}$ \\
R113 & Trichlorotrifluoroethane & $\mathrm{CCl}_{2} \mathrm{FCClF}_{2}$ \\
R114 & Dichlorotetrafluoroethane & $\mathrm{ClF}_{2} \mathrm{C}-\mathrm{CClF}_{2}$ \\
\hline
\end{tabular}

\subsection{Arranging Power Plant}

Specification of flue gas shown in Table 1 is the basic and important data to design and analyze the system. It should be noted that there are two production lines in the flat glass factory each of individual stack. It is therefore both flue gas lines will be merged into a single heat source. Beside Figure 1, Figure 3, on the other hand, exhibits a combined cycle system which is simulated using Cycle Tempo software. 
Combined cycle system is a combination of WSRC and Organic Rankine Cycle (ORC). ORC consists of evaporator, turbine, condenser and pump. In the combined cycle system, waste heat of the condensing turbine is then uti- lized as the heat source of ORC. Refrigerant, the working fluid of ORC, evaporate in evaporator. The refrigerant gas afterward expanded in the turbine where thermal energy converted mechanical energy.

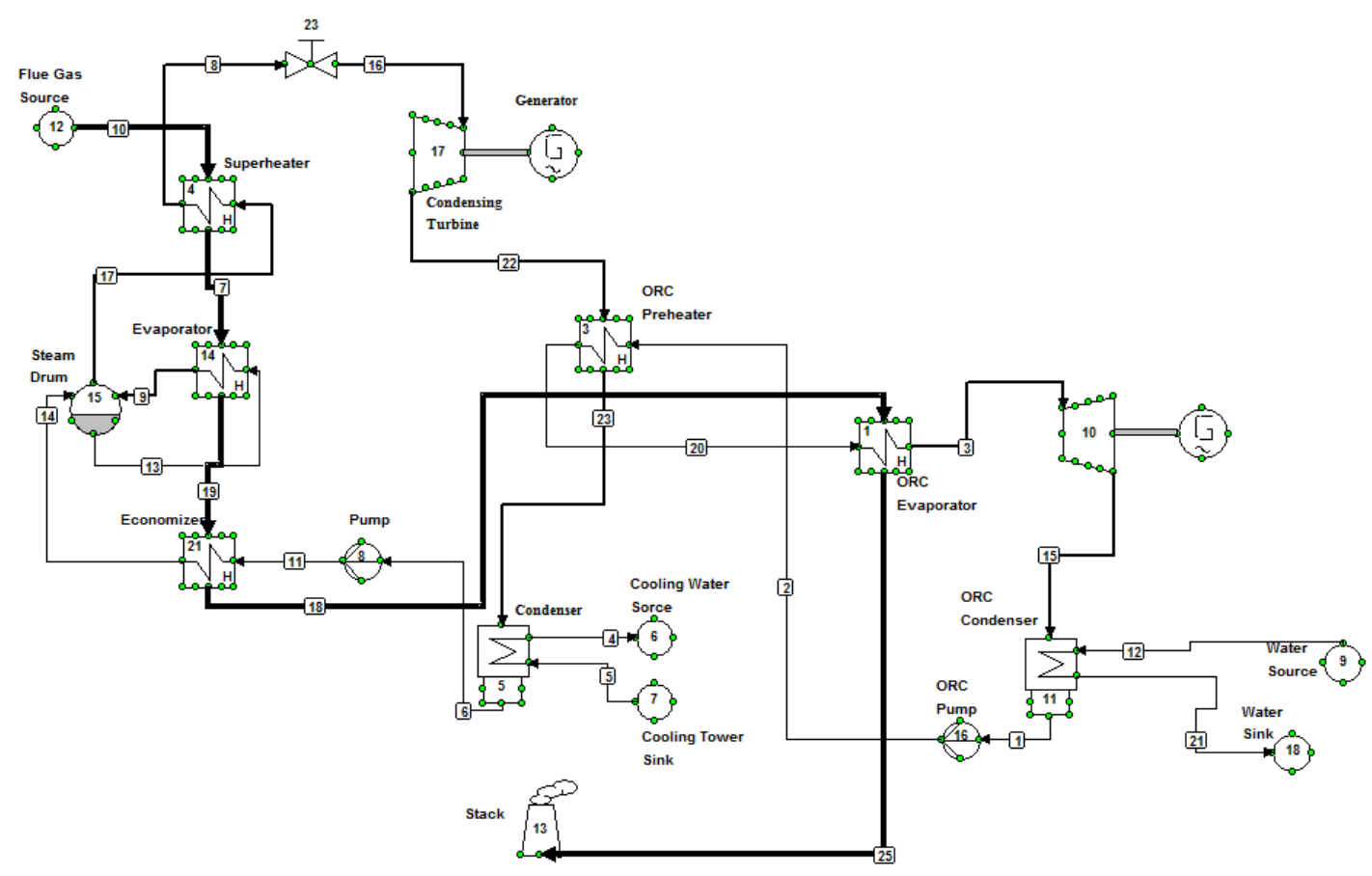

Figure 3. Cycle Tempo Modeling for Condensing Turbine.

Table 3. Starting Parameter in Cycle Tempo Software.

\begin{tabular}{|c|c|c|c|c|}
\hline No & Components & Parameter & Data Input & Unit \\
\hline \multirow[t]{3}{*}{1} & Flue gas source & Flue gas enter HRSG system such as: & & \\
\hline & & Mass flow rate & 43 & $\mathrm{~kg} / \mathrm{s}$ \\
\hline & & Temperature (T) & 493 & ${ }^{\circ} \mathrm{C}$ \\
\hline \multirow[t]{2}{*}{2} & Stack & Flue gas exit from HRSG system, such as: & & \\
\hline & & Temperature (T) & 158 & ${ }^{\circ} \mathrm{C}$ \\
\hline \multirow[t]{3}{*}{3} & Condensing Turbine & Saturated condition of working fluid (steam), such as: & & \\
\hline & & Temperature $(\mathrm{T})$ & 53.97 & ${ }^{\circ} \mathrm{C}$ \\
\hline & & Pressure (P) & 0.15 & bar \\
\hline \multirow{2}{*}{4} & HRSG Evaporator & Flue gas exit from evaporator & & \\
\hline & & Temperature (T) & 255 & ${ }^{\circ} \mathrm{C}$ \\
\hline
\end{tabular}

Refrigerant from turbine is going to be condensed by condenser and then is pumped to preheater. In addition, the function of preheater is to heat refrigerant to higher temperature. Heat source of preheater is exhaust steam of turbine. From Figure 3 , it is shown that a preheater is placed between steam turbine and condenser. This preheater benefits the ORC as it can increase the working fluid temperature. To complete the cycle, the refrigerant is then evaporate by the flue gas.

\subsection{Thermodynamic Analysis}

Cycle Tempo software can be used to design an optimal power plant arrangement [4]. In this study, Cycle Tempo is used to analyze the effect of variation of steam mass flow rate, evaporating temperature, and the flue gas temperatures on the performance of combined cycle and will be compared with the performance of Water-Simple Rankine Cycle (WSRC). Table 4 shows the variation which is applied in both system 
Table 4. Variation of Both Systems

\begin{tabular}{|c|c|c|c|c|c|c|}
\hline No & System & $\begin{array}{l}\dot{m} \\
(\mathrm{~kg} / \mathrm{s})\end{array}$ & $\begin{array}{l}\text { Evaporating } \\
\mathrm{T}\left({ }^{\circ} \mathrm{C}\right)\end{array}$ & $\begin{array}{l}\text { Flue Gas } \\
\mathrm{T}\left({ }^{\circ} \mathrm{C}\right)\end{array}$ & Refrigerant & Turbine Inlet $\mathrm{T}\left({ }^{\circ} \mathrm{C}\right)$ \\
\hline 1 & Condensing Turbine & & 140 & 158 & $\begin{array}{l}\text { R-11 } \\
\text { R-13 } \\
\text { R-14 }\end{array}$ & $150,170,200$ \\
\hline $\begin{array}{l}2 \\
3\end{array}$ & Combined & $\begin{array}{l}4.3 \\
4.6\end{array}$ & 160 & 158 & $\begin{array}{l}\mathrm{R}-11 \\
\mathrm{R}-13^{a}\end{array}$ & $170,185,200$ \\
\hline 4 & cycle & 5 & 140 & 120 & $\begin{array}{l}\text { R-11 } \\
\text { R-13 } \\
\text { R-14 }\end{array}$ & $150,170,200$ \\
\hline
\end{tabular}

${ }^{a} \mathrm{R}-114$ is not applicable, because of its lower critical point $\left(143^{\circ} \mathrm{C}\right)[5]$.

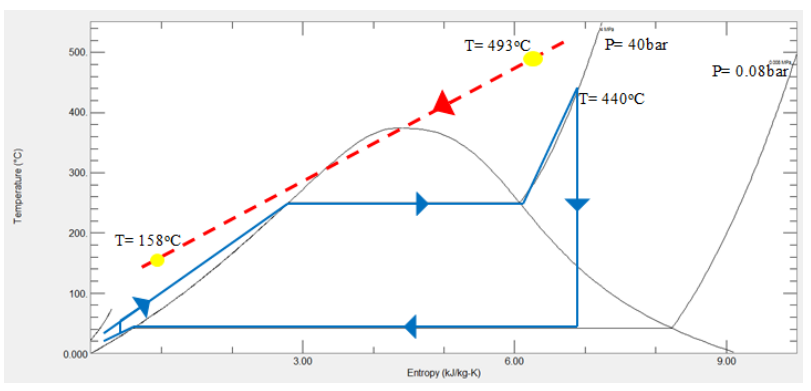

Figure 4. Distribution Temperature of Water-Simple Rankine Cycle.

The following are thermodynamic formulas to perform the thermal analyze both system:

- Absorbed Heat by HRSG

$$
\dot{Q}_{\text {absorb }}=\dot{m}_{\text {fluegas }} c_{p, \text { fluegas }} \Delta T_{H R S G}
$$

- Gross power output

$$
\dot{W}_{\text {gross }}=\dot{W}_{S T}+\dot{W}_{O R C}
$$

- Turbine power output

$$
\begin{gathered}
\dot{W}_{S T}=\dot{m}_{\text {steam }} \quad S T \quad\left(h_{\text {in }, S T}-h_{\text {out }, S T}\right) \\
\dot{W}_{S T}=\dot{m}_{\text {ref }} \quad \text { ORC } \quad\left(h_{\text {in }, \text { ORC }}-h_{\text {out }, \text { ORC }}\right)
\end{gathered}
$$

Where,

$C_{p, \text { fluegas }}=$ Specific heat of flue gas $(\mathrm{kJ} / \mathrm{kg})$

$\dot{m}_{\text {fluegas }}=$ mass flow rate flue gas $(\mathrm{kg} / \mathrm{s})$

$\dot{m}_{\text {steam }}=$ mass flow rate $\operatorname{steam}(\mathrm{kg} / \mathrm{s})$

$\dot{m}_{\text {ref }}=$ mass flow rate refrigerant $(\mathrm{kg} / \mathrm{s})$

$\dot{W}_{S T}=$ power of steam $(\mathrm{kW})$

$\dot{W}_{O R C}=$ power of ORC $(\mathrm{kW})$

$\dot{Q}_{\text {absorb }}=$ heat transfer by flue gas HRSG $(\mathrm{kW})$

\section{Results and Discussion}

\subsection{Water-Simple Rankine Cycle (WSRC)}

Figure 4 depicts temperature distribution of flue gas and water in condensing turbine system. Operating pressure and temperature of steam is 40 bar and $440^{\circ} \mathrm{C}$ respectively. The HRSG pinch point (difference between evaporating temperature of steam and flue gas temperature out from economizer) is set at ${ }^{\circ}$. Running Cycle Tempo 5.1 software, it is found that the condensing turbine yield maximum power of 5.77 MW with the flue gas temperature in stack of $158^{\circ} \mathrm{C}$.

Temperature of flue gas in the economizer differs for each steam mass flow rate. The lower the steam mass flow rate, the higher the flue gas temperatures exiting the economizer. The limiting conditions of WSRC are stack's temperature $\left(255^{\circ} \mathrm{C}\right)$ and water enthalpy $(1085 \mathrm{~kJ} / \mathrm{kg})$ in economizer. These limits acquired steam mass flow rate of $4.3 \mathrm{~kg} / \mathrm{s}$ to $5.4 \mathrm{~kg} / \mathrm{s}$ and flue gas temperature in stack of $251^{\circ} \mathrm{C}$ to $158^{\circ} \mathrm{C}$. Based on the result of Cycle Tempo simulation, the performance in $5.4 \mathrm{~kg} / \mathrm{s}$ steam will be compared to that of combined cycle.

\subsection{Combined Cycle System Modeling}

3.2.1. Steam Mass Flow Rate Variations Effects for Combined Cycle Performance

Table 5 explains that steam mass flow rate variation affects the performance of combined cycle system. An increase in steam mass flow rate will decrease the performance of ORC - R11. With evaporating temperature of $140^{\circ} \mathrm{C}$, two other refrigerants: R-113 and R-114, are also evaluate their performance. Figure 5 shows the effect of steam mass flow rate and refrigerant for combined cycle performance with varied turbine inlet temperature(TIT) of $150^{\circ} \mathrm{C}, 170^{\circ} \mathrm{C}$, and $200^{\circ} \mathrm{C}$. The condition of flue gas, mass flow rate and temperature is constant for each variation.

When $4.3 \mathrm{~kg} / \mathrm{s}$ of steam is used, the performance of combined cycle system is lower than that of the WaterSimple Rankine Cycle (WSRC). Figure 5a explains that the maximum performance of the lowest mass flow rate is 
5.61 MW using R-11 as working fluid. The overall performance using steam mass flow rate of $4.3 \mathrm{~kg} / \mathrm{s}$ is slightly less than that using steam mass flow rate $4.6 \mathrm{~kg} / \mathrm{s}$. Figure 5b shows that the performance of combined cycle using $4.6 \mathrm{~kg} / \mathrm{s}$ is still lower than the performance of WSRC. The graph shows that the maximum performance of combined cycle system is $5.74 \mathrm{MW}$ using working fluid R-11. Figure 5f shows that the highest performance is 5.89 MW using steam mass flow rate is $5 \mathrm{~kg} / \mathrm{s}$ and R-11 as working fluid, which is around two percent above Water-Simple Rankine Cycle's performance. Despite these seemingly contradicting trends, the performance of WSRC contributes more to the performance of combined cycle, which is shown in Figure 6

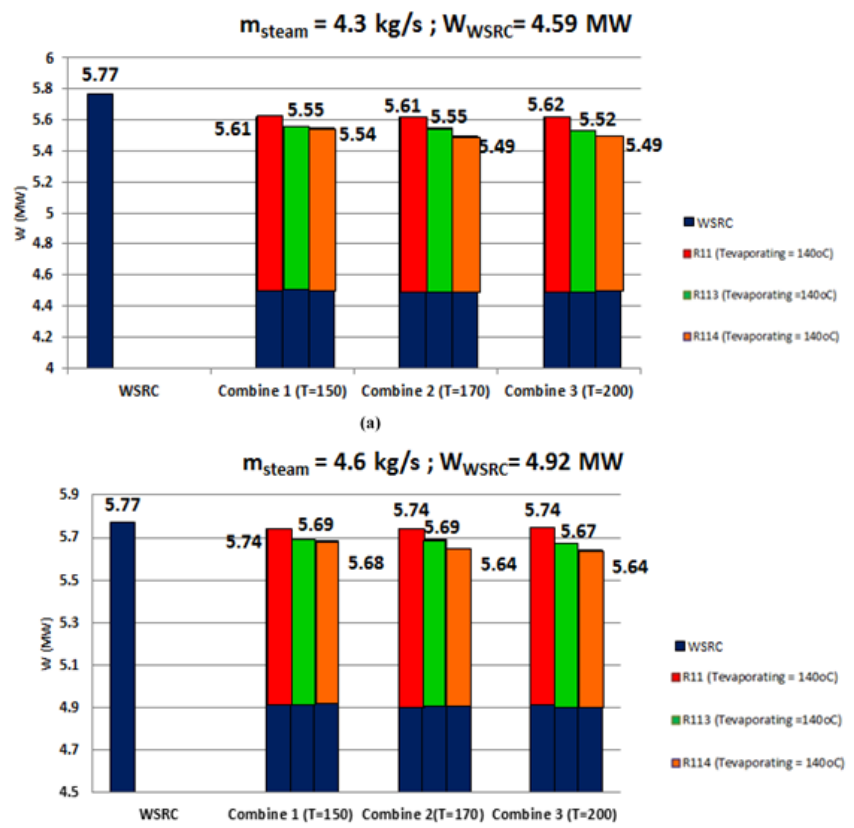

(b)

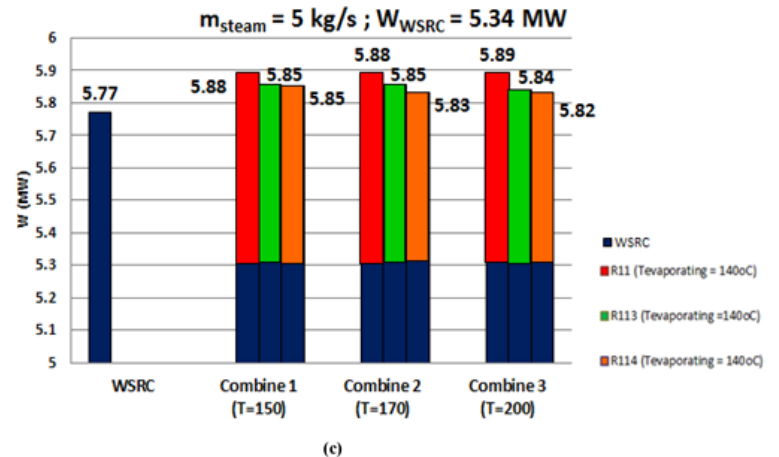

Figure 5. Effect of Steam Mass Flow Rate Variation (a) $4.3 \mathrm{~kg} / \mathrm{s}$, (b) $4.6 \mathrm{~kg} / \mathrm{s}$, (c) $5 \mathrm{~kg} / \mathrm{s}$ for Combined Cycle Performance with Tevap $=140^{\circ} \mathrm{C}$.

3.2.2. Evaporating Temperature Variation Effects for Combined Cycle Performance

This study also varies the evaporating temperature from $140^{\circ} \mathrm{C}$ to $160^{\circ} \mathrm{C}$. Based on Equation 2 and Equation 3 , an increase in the enthalpy difference will yield a higher performance in turbine. Figure 7 shows that generally the performance of combined cycle system will increase with the increase of evaporating temperature. Figure $7 \mathrm{a}$ exhibits that the increase in performance of combined cycle with $4.3 \mathrm{~kg} / \mathrm{s}$ steam mass flow rate is still not sufficient to surpass that of condensing turbine's performance. When using $140^{\circ} \mathrm{C}$ (Figure 6b) as the evaporating temperature, the overall performance of combined cycle for $4.6 \mathrm{~kg} / \mathrm{s}$ is lower than that of Water-Simple Rankine Cycle's performance. Meanwhile, the overall performance for 4.6 $\mathrm{kg} / \mathrm{s}$ is higher than WSRC's performance when the evaporating temperature reaches $160^{\circ} \mathrm{C}$, as shown by Figure 7b. Figure 7f shows that a steam mass flow rate of 5 $\mathrm{kg} / \mathrm{s}$ produces maximum power around $5.96 \mathrm{MW}$ or 3.2 percent above the performance of Water-Simple Rankine Cycle. Maximum power for each steam mass flow rate is owned by R-11 with a TIT of $200^{\circ} \mathrm{C}$. 
3.2.3. Temperature Flue Gas in Stack Variation Effects for Combined Cycle Performance

The initial setup of flue gas temperature in combined cycle system is $158^{\circ} \mathrm{C}$. However, the condition does not yield a salient increase in combined cycle performance. By decreasing the flue gas temperature, more heat is delivered to the evaporator in the ORC system, thereby increasing combined cycle performance. This study limits the lowest temperature of flue gas at $120^{\circ} \mathrm{C}$ due to dew point of sulfur.Figure 8 shows the effect of temperature flue gas in stack decreases with the same condition of steam mass flow rate and TIT from $150^{\circ} \mathrm{C}$ to $200^{\circ} \mathrm{C}$. With flue gas temperature in stack is $158^{\circ} \mathrm{C}$, the performance of combined cycle is two percent above performance of WSRC. When flue gas temperature decreased, performance of combined cycle is 9.2 percent above performance of Water-
Simple Rankine Cycle. Decreasing flue gas temperature in stack, results in higher combined cycle performance due to greater ORC contribution.

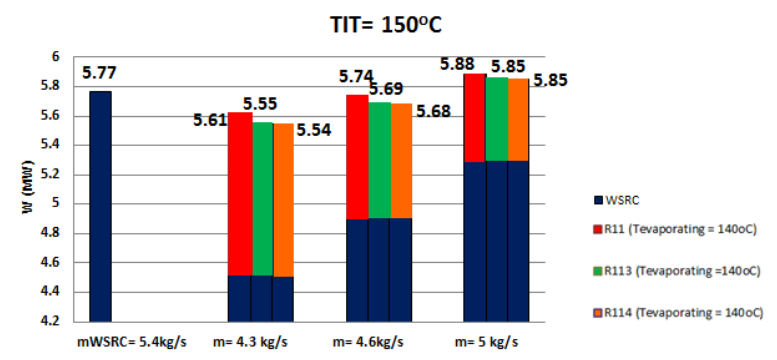

Figure 6. Effect of Steam Mass Flow Rate Variation ORC Performance with Tevap $=140^{\circ} \mathrm{C}$.

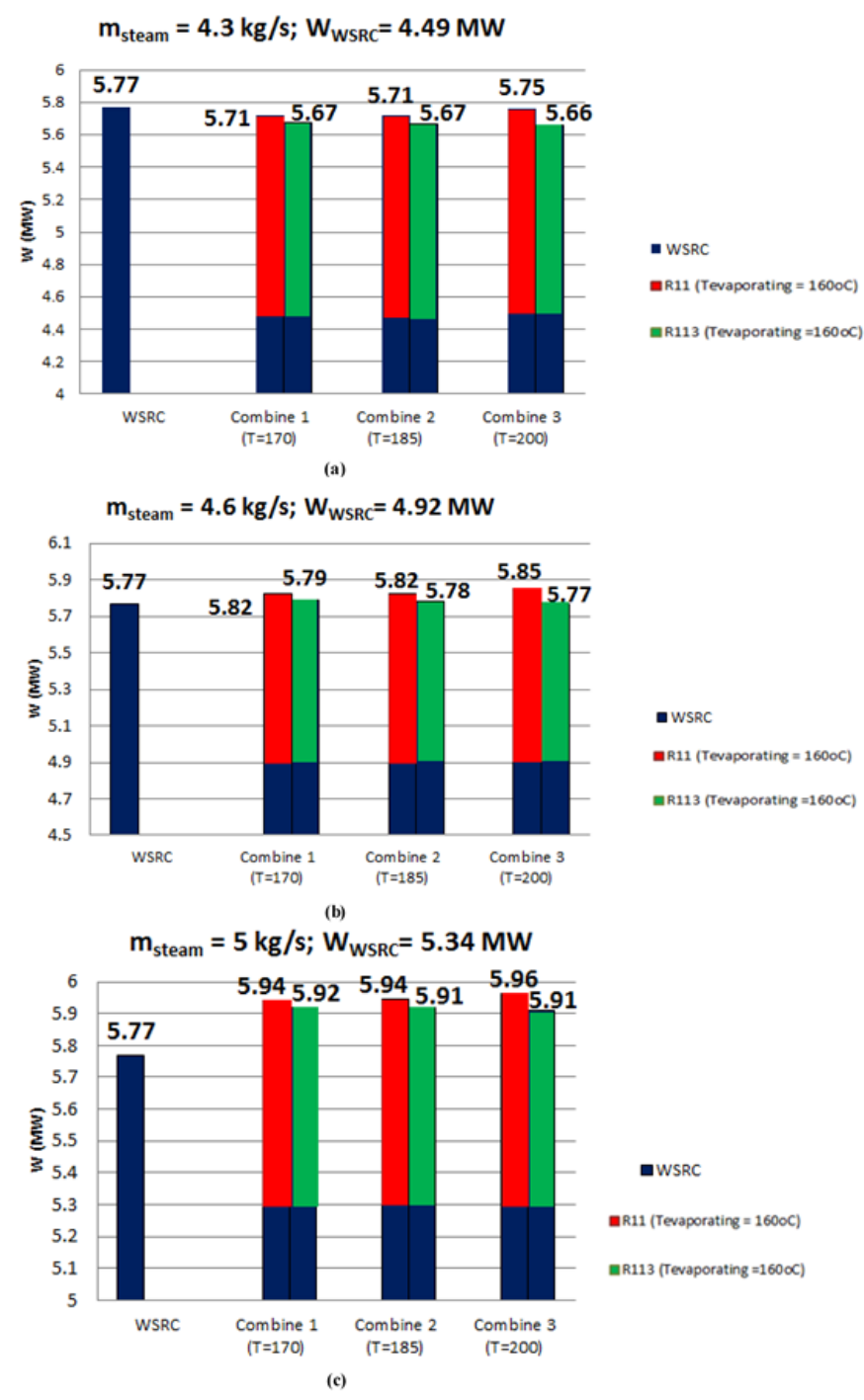

Figure 7. Effect of Steam Mass Flow Rate Variation (a) $4.3 \mathrm{~kg} / \mathrm{s}$, (b) $4.6 \mathrm{~kg} / \mathrm{s}$, (c) $5 \mathrm{~kg} / \mathrm{s}$ for Combined Cycle Performance with Tevap $=160^{\circ} \mathrm{C}$. 
Table 5. Effect of Steam Mass Flow Rate Variation for ORC Performance

\begin{tabular}{cclrr}
\hline $\begin{array}{l}\dot{m}_{\text {steam }} \\
(\mathrm{kg} / \mathrm{s})\end{array}$ & $\begin{array}{l}\mathrm{T}_{\text {ecofluegas }} \\
\left({ }^{\circ} \mathrm{C}\right)\end{array}$ & $\begin{array}{l}\mathrm{Q} \\
(\mathrm{MW})\end{array}$ & $\begin{array}{l}\mathrm{TIT}_{\text {ORC }} \\
\left({ }^{\circ} \mathrm{C}\right)\end{array}$ & $\begin{array}{l}\mathrm{W}_{\text {ORC }} \\
\mathrm{MW}\end{array}$ \\
\hline 4.3 & 251 & 4398.9 & 150 & 1.028 \\
& & & 200 & 1.03 \\
4.6 & 233 & 3547.5 & 150 & 0.823 \\
& & & 200 & 0.824 \\
5 & 208 & 2365 & 150 & 0.549 \\
& & & 200 & 0.55 \\
\hline
\end{tabular}

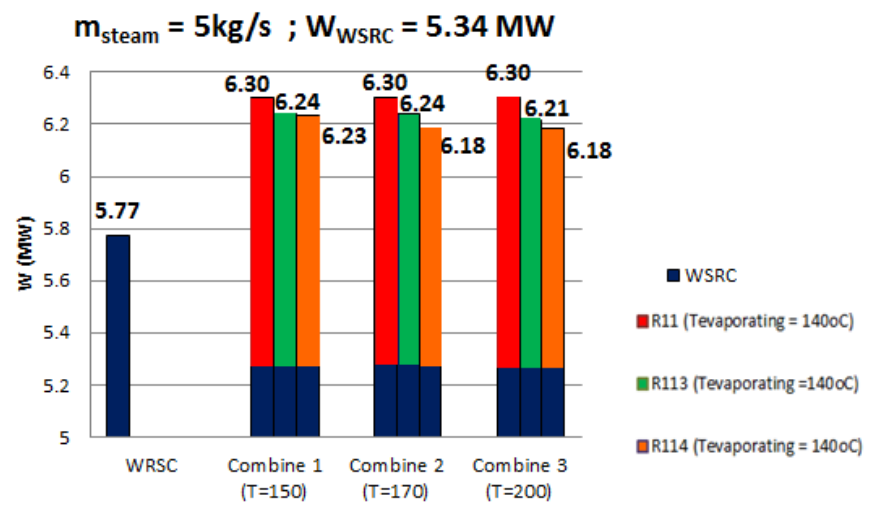

Figure 8. Decreasing Temperature Flue Gas in Stack Effects for Combined Cycle Performance.

\section{Conclusions}

Two system schemes utilizing waste heat is presented. Steam mass flow rate, evaporating temperature, and flue gas temperature in stack are varied. The conclusions of this study are the following:

1. In Water-Simple Rankine Cycle (WSRC), the steam mass flow rate ranges from $4.3 \mathrm{~kg} / \mathrm{s}-5.4 \mathrm{~kg} / \mathrm{s}$, while the temperature ranged of flue gas in stack is $158^{\circ} \mathrm{C}$ $251^{\circ} \mathrm{C}$. The highest steam mass flow rate generates 5.77 MW. In combined cycle, steam mass flow rate is varied $4.3 \mathrm{~kg} / \mathrm{s}, 4.6 \mathrm{~kg} / \mathrm{s}$ and $5 \mathrm{~kg} / \mathrm{s}$. The result is $5.89 \mathrm{MW}$ as the highest performance is generated by mass flow rate of steam $5 \mathrm{~kg} / \mathrm{s}$. There is $2 \%$ above Water-Simple Rankine Cycle (WSRC).

2. Increasing evaporating temperature results in higher ORC performance, thus higher combined cycle per- formance. Increasing evaporating temperature from $140^{\circ} \mathrm{C}$ to $160^{\circ} \mathrm{C}$ in combined cycle yield the performance of 3.2\% above Water-Simple Rankine Cycle (WSRC).

3. Decreasing flue gas temperature at stack from $158 \mathrm{C}$ to $120^{\circ} \mathrm{C}$ in combined cycle yield the result the performance is $9.2 \%$ above Water-Simple Rankine Cycle (WSRC).

4. Three kinds of refrigerant are used in Organic Rankine Cycle (ORC). There are R-11, R-113 and R-114. Overall, increasing of turbine inlet temperature (TIT) in ORC refrigerant does not affect the performance of combined cycle.

\section{References}

[1] Z. Li, X. He, Y. Wang, B. Zhang, and H. He, "Design of a flat glass furnace waste heat power generation system," Applied Thermal Engineering, vol. 63, no. 1, pp. 290-296, 2014.

[2] F. Punjung and Prabowo, "Perancangan termal waste heat recovery power generation (whrpg) pada industri floating glass (studi kasus pt. asahimas flat glass tbk," Jurnal Teknik ITS, 2016.

[3] M. Moran and H. Shapiro, FUNDAMENTALS OF ENGINEERING THERMODYNAMICS, 6TH ED. Wiley India Pvt. Limited, 2010.

[4] TU DELFT, Reference Guide Cycle Tempo, 2016.

[5] Refrigerant Reference Guide Fifth Edition. Philadelpia: National Refrigerants, Inc., 2011. 